\title{
Sistem Pendukung Keputusan Menentukan Kelayakan Bantuan Ternak Oleh Dinas Ketahanan Pangan Dan Peternakan PROVSU Menggunakan Metode WASPAS
}

Decision Support System Determines the Feasibility of Animal Assistance by the Food Security and Livestock Services Office of PROVSU Using the WASPAS Method

\author{
Ronal Hottonny Siallagan ${ }^{1}$, Safrizal ${ }^{2}$ \\ ${ }^{1,2}$ Program Studi Sistem Informasi, Fakultas Teknik dan Ilmu Komputer \\ Universitas Potensi Utama, Jl.K.L. Yos Sudarso KM 6.5 Tanjung Mulia-Medan \\ Email :ronaljob314@gmail.com ${ }^{1}$,rizalsyl75@gmail.com ${ }^{2}$
}

\begin{abstract}
ABSTRAK
Dinas Ketahanan Pangan dan Peternakan Provinsi Sumatera Utara dalam memberikan bantuan tidak menggunakan cara perhitungan khusus seperti menggunakan metode ilmiah. Proses yang berjalan pada Dinas Ketahanan Pangan Dan Peternakan Provinsi Sumatera Utara dalam memberi penilaian untuk melakukan pemberian bantuan ternak, Dinas Ketahanan Pangan Dan Peternakan Provinsi Sumatera Utara masih menggunakan penilaian umum yaitu dengan melakukan penjumlahan keseluruh kriteria(syarat) yang sudah terkumpul. Dan siapa yang paling lengkap mengumpulkan persyaratan tersebut, maka berpeluang besar mendapatkan bantuan ternak oleh Dinas Ketahanan Pangan Dan Peternakan Provinsi Sumatera Utara. Sehingga dalam penerapan bantuan ternak ini masih dirasa kurang relevan. Hal ini dikarenakan pihak Instansi tidak melihat tingkat kepentingan dari setiap kriteria yang ada atau dengan kata lain menyamakan semua nilai setiap kriteria yang ada. Penilaian untuk kelayakan bantuan ternak ini dirasa masih tidak objektif untuk menyelesaikan permasalahan dibutuhkan sistem pendukung keputusan yang handal, yaitu dengan menggunakan metode Weighted Aggregated Sum Product Assesment (WASPAS). Dengan adanya sistem pendukung keputusan dapat meningkatkan kualitas keputusan yang akan dibuat. Hasil dari penerapan metode WASPAS ini dapat menghasilkan alternatif kelompok tani/ternak yang tepat sesuai dengan kriteria yang diinginkan instansi.
\end{abstract}

Kata Kunci : Sistem Pendukung Keputusan, Bantuan Ternak, WASPAS

\section{ABSTRACT}

The Food and Animal Husbandry Service of North Sumatra Province in providing assistance does not use special calculations such as using scientific methods. The process that is running at the North Sumatra Province Food and Animal Security Service in assessing the provision of livestock assistance, the North Sumatra Province Food and Animal Security Service still uses a general assessment, namely by summing all the collected criteria (requirements). And whoever is most complete in collecting these requirements has a big chance of getting livestock assistance by the Food and Animal Husbandry Service of North Sumatra Province. So that the application of livestock assistance is still considered less relevant. This is because the agency does not see the level of importance of each existing criterion or in other words equalizes all the values of each existing criterion. The assessment for the appropriateness of livestock assistance is deemed not objective to solve the problem. It requires a reliable decision support system, namely by using the Weighted Aggregated Sum Product Assessment (WASPAS) method. With the decision support system, it can improve the quality of the decisions to be made. The results of the application of the WASPAS method can produce appropriate alternative farmer / livestock groups according to the criteria desired by the agency.

Keywords: Decision Support System, Animal Assistance, WASPAS 


\section{PENDAHULUAN}

Permasalahan umum yang sering terjadi yaitu Dinas Ketahanan Pangan dan Peternakan Provinsi Sumatera Utara dalam memberikan bantuan sering sekali bantuan ternak tidak sesuai sasaran dan bantuan ternak yang diberi tidak terurus dengan baik dikarenakan sering sekali kelompok tani/ternak sesudah mendapat bantuan setelah dicek kembali ternak yang diberi tidak terurus dengan baik.

Dalam melakukan pemberian bantuan ternak masih dilakukan dengan menggunakan proses manual, yaitu Dinas Ketahanan Pangan dan Peternakan Provinsi Sumatera Utara dalam memberikan bantuan tidak menggunakan cara perhitungan khusus seperti menggunakan metode ilmiah dalam menentukan kelayakan bantuan ternak.Mengingat zaman yang terus berubah dan berkembang yang tidak bisa dibantah oleh manusia pembaharuan dalam segala hal kearah yang lebih ilmiah pasti akan terjadi begitu juga dalam memberi bantuan ternak kepada kelompok tani/ternak dapat juga menggunakan pendekatan ilmiah.

Proses yang berjalan pada Dinas Ketahanan Pangan Dan Peternakan Provinsi Sumatera Utara dalam memberi penilaian untuk melakukan pemberian bantuan ternak, Dinas Ketahanan Pangan Dan Peternakan Provinsi Sumatera Utara Masih menggunakan penilaian mainstream yaitu dengan melakukan penjumlahan keseluruh kriteria yang sudah terkumpul. Dan kelompok siapa yang paling lengkap mengumpulkan persyaratan tersebut, maka berpeluang besar mendapatkan bantuan ternak oleh Dinas Ketahanan Pangan Dan Peternakan Provinsi Sumatera Utara.Sehingga dalam penerapan bantuan ternak ini masih dirasa kurang relevan. Hal ini dikarenakan pihak Instansi tidak melihat tingkat kepentingan dari setiap kriteria yang ada atau dengan kata lain menyamakan semua nilai setiap kriteria yang ada.Penulis menyadari sebuah metode dibutuhkan untuk melakukan penilaian dalam memberikan bantuan ternak oleh Dinas Ketahanan Pangan Dan Peternakan Provinsi Sumatera Utara agar sebuah penilaian itu bisa bersifat objektif.

Sistem pendukng keputusan merupakan sebuah pengambilan keputusan dengan menggunakan sebuah sistem berbasis komputer [1]. Sistem pendukung keputusan dapat juga digunakan untuk mendukung sebuah instansi dalam melakukan perkerjaan yang bersifat analitis pada situasi kurang baik dan dengan kriteria yang kurang jelas [8]. Penerapan Sistem Pendukung Keputusan biasanya menggunakan sebuah metode-metode berbasis multikriteria, seperti metode SAW[3], ARAS[4], Profile Matching[5], ELECTRE[6], Weighted Product[7], Promethee[9], MOORA[10]. Metode Weighted Aggregated Sum Product Assesment(WASPAS) merupakan metode kombinasi dari metode WP dan metode SAW, metode WASPAS ini diharapkan dapat memberikan hasil yang lebih baik dalam membantu penentuan sistem pendukung keputusan [15]. Maka akan dibuat solusi terbaik untuk membantu mengambil keputusan menentukan kelayakan bantuan ternak menggunakan metode Weighted Aggregated Sum Product Assesment (WASPAS). Alasan menggunakan metode ini adalah karena metode ini didefinisikan sebagai multikriteria pengambilan keputusan(MCDM) yang dapat dilihat pada pemilihan dari serangkaian alternatif berdasarkan kriteria.

\section{METODE PENELITIAN}

Dalam penelitian ini metode pengembangan sistem yang digunakan penulis adalah dengan menggunakan waterfall. Kelebihan model waterfall mempermudah penulis dalam mengaplikasikannya dan memiliki proses yang urut. Berikut adalah tahapan-tahapan model waterfall yang digunakan, dapat dilihat pada gambar di bawah ini: 


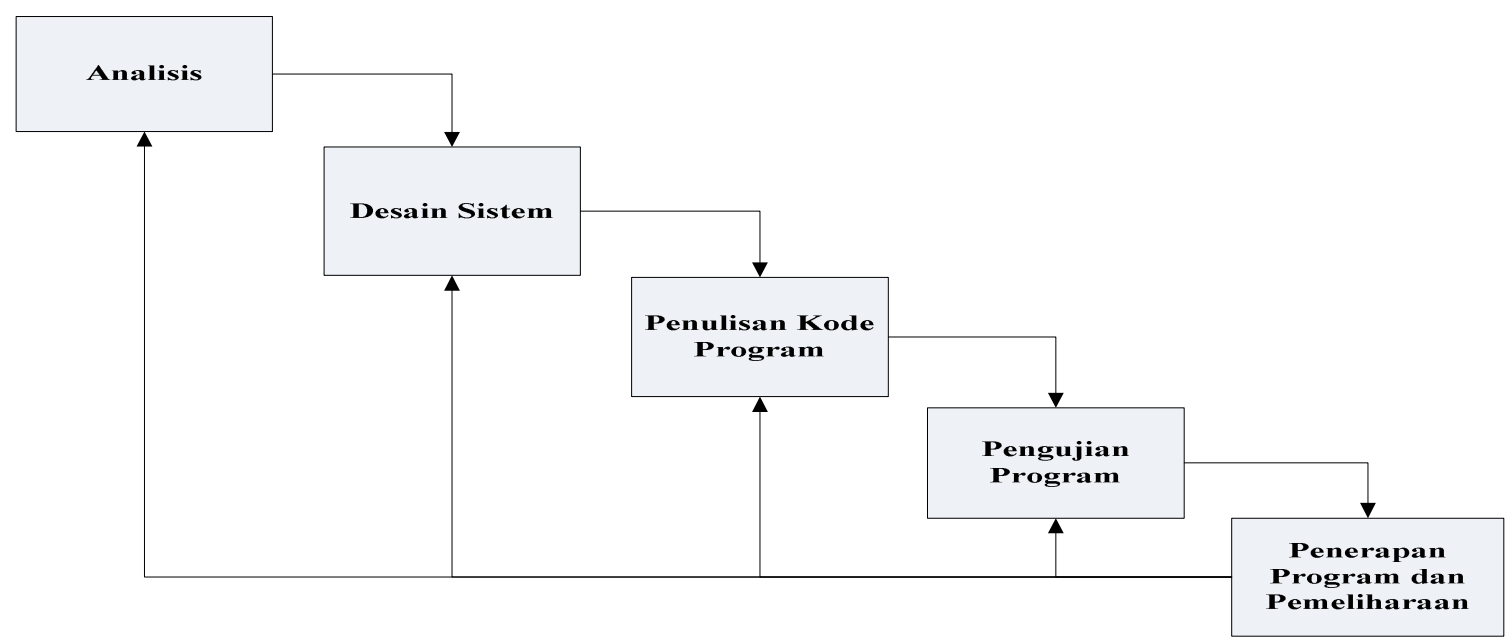

Gambar 1. Waterfall

\section{HASIL DAN PEMBAHASAN}

Sebelum masuk ke langkah-langkah perhitungan metode WASPAS sebelumnya kita harus memberikan nilai pada setiap kriteria dan alternatif terlebih dahulu.

Tabel 1. Kriteria

\begin{tabular}{|c|c|c|c|c|}
\hline Kriteria & Keterangan & Nilai & Bobot & Jenis \\
\hline \multirow{2}{*}{$\begin{array}{l}\text { Rekomendasi Dinas Yang Menangani Di } \\
\text { KAB/KOTA(K1) }\end{array}$} & Ada & 2 & \multirow{2}{*}{$20 \%$} & \multirow{2}{*}{ Benefit } \\
\hline & Tidak Ada & 1 & & \\
\hline \multirow{2}{*}{ Berita Acara Pembentukan Kelompok(K2) } & Ada & 2 & \multirow{2}{*}{$5 \%$} & \multirow{2}{*}{ Benefit } \\
\hline & Tidak Ada & 1 & & \\
\hline \multirow{2}{*}{$\begin{array}{l}\text { Surat Keputusan Pembentukan Kelompok Dari } \\
\text { Kepla Desa(K3) }\end{array}$} & Ada & 2 & \multirow{2}{*}{$10 \%$} & \multirow{2}{*}{ Benefit } \\
\hline & Tidak Ada & 1 & & \\
\hline \multirow{2}{*}{ Sertifikat Kelas Kelompok Tani(K4) } & Ada & 2 & \multirow{2}{*}{$5 \%$} & \multirow{2}{*}{ Benefit } \\
\hline & Tidak Ada & 1 & & \\
\hline \multirow{2}{*}{ AD/ART Kelompok(K5) } & Ada & 2 & \multirow{2}{*}{$10 \%$} & \multirow{2}{*}{ Benefit } \\
\hline & Tidak Ada & 1 & & \\
\hline \multirow[t]{2}{*}{ Akte Notaris/SK Kemenkumham(K6) } & Ada & 2 & \multirow{2}{*}{$10 \%$} & \multirow{2}{*}{ Benefi } \\
\hline & Tidak Ada & 1 & & \\
\hline \multirow[t]{2}{*}{ Simluhtan(K7) } & Ada & 2 & \multirow{2}{*}{$10 \%$} & \multirow{2}{*}{ Benefit } \\
\hline & Tidak Ada & 1 & & \\
\hline \multirow{2}{*}{ KTP Pengurus dan Anggota Kelompok Tani(K8) } & Ada & 2 & \multirow{2}{*}{$5 \%$} & \multirow{2}{*}{ Benefit } \\
\hline & Tidak Ada & 1 & & \\
\hline \multirow[t]{2}{*}{$\begin{array}{l}\text { Keberadaan Pakan Ternak Kelompok Tani/Ternak } \\
\text { (K9) }\end{array}$} & Ada & 2 & \multirow{2}{*}{$15 \%$} & \multirow{2}{*}{ Benefit } \\
\hline & Tidak Ada & 1 & & \\
\hline \multirow[t]{2}{*}{ Ketersediaan Kandang Ternak (K10) } & Ada & 2 & \multirow{2}{*}{$10 \%$} & \multirow{2}{*}{ Benefit } \\
\hline & Tidak Ada & 1 & & \\
\hline
\end{tabular}


Tabel 2. Alternatif

\begin{tabular}{|c|l|c|c|c|c|c|c|c|c|c|c|}
\hline No & \multicolumn{1}{|c|}{ Kelompok } & K1 & K2 & K3 & K4 & K5 & K6 & K7 & K8 & K9 & K10 \\
\hline 1 & Karya Bakti & $\sqrt{ }$ & X & X & X & $\sqrt{ }$ & X & $\sqrt{ }$ & $\sqrt{ }$ & X & X \\
\hline 2 & Serba Guna & X & X & $\sqrt{ }$ & $\sqrt{ }$ & $\sqrt{ }$ & X & $\sqrt{ }$ & $\sqrt{ }$ & X & X \\
\hline 3 & Makmur & $\sqrt{ }$ & X & X & X & $\sqrt{ }$ & $\sqrt{ }$ & $\sqrt{ }$ & $\sqrt{ }$ & X & X \\
\hline 4 & Makmur II & X & $\sqrt{ }$ & $\sqrt{ }$ & $\sqrt{ }$ & $\sqrt{ }$ & $\sqrt{ }$ & $\sqrt{ }$ & $\sqrt{ }$ & X & X \\
\hline 5 & Bahagia & $\sqrt{ }$ & X & $\sqrt{ }$ & $\sqrt{ }$ & $\sqrt{ }$ & $\mathrm{X}$ & $\sqrt{ }$ & $\sqrt{ }$ & X & X \\
\hline 6 & Sugeh Bareng & $\sqrt{ }$ & $\mathrm{X}$ & $\sqrt{ }$ & $\mathrm{X}$ & $\mathrm{X}$ & $\mathrm{X}$ & $\sqrt{ }$ & $\mathrm{X}$ & $\mathrm{X}$ & $\mathrm{X}$ \\
\hline 7 & Sri Sari Wangi & $\sqrt{ }$ & $\mathrm{X}$ & $\sqrt{ }$ & $\mathrm{X}$ & $\sqrt{ }$ & $\mathrm{X}$ & $\sqrt{ }$ & $\sqrt{ }$ & $\mathrm{X}$ & $\mathrm{X}$ \\
\hline 8 & Makmur Jaya & $\sqrt{ }$ & $\mathrm{X}$ & $\sqrt{ }$ & $\mathrm{X}$ & $\sqrt{ }$ & $\mathrm{X}$ & $\sqrt{ }$ & $\mathrm{X}$ & $\mathrm{X}$ & $\mathrm{X}$ \\
\hline 9 & Harum Sari & $\mathrm{X}$ & $\sqrt{ }$ & $\mathrm{X}$ & $\sqrt{ }$ & $\sqrt{ }$ & $\sqrt{ }$ & $\sqrt{ }$ & $\sqrt{ }$ & $\mathrm{X}$ & $\mathrm{X}$ \\
\hline 10 & Brahman & & & & & & & & & \\
\hline
\end{tabular}

Dimana:

$\sqrt{ }=$ Data kriteria alternatif ada

$\mathrm{X}=$ Data kriteria alternatif tidak ada

Tabel 3. Rating Kecocokan Alternatif dan Kriteria

\begin{tabular}{|c|l|c|c|c|c|c|c|c|c|c|c|}
\hline No & \multicolumn{1}{|c|}{ Alternatif } & K1 & K2 & K3 & K4 & K5 & K6 & K7 & K8 & K9 & K10 \\
\hline 1 & Karya Bakti & 2 & 1 & 1 & 1 & 2 & 1 & 2 & 2 & 1 & 1 \\
\hline 2 & Serba Guna & 1 & 1 & 2 & 2 & 2 & 1 & 2 & 2 & 1 & 1 \\
\hline 3 & Makmur & 2 & 1 & 1 & 1 & 2 & 2 & 2 & 2 & 1 & 1 \\
\hline 4 & Makmur II & 2 & 1 & 2 & 2 & 2 & 2 & 2 & 1 & 1 & 1 \\
\hline 5 & Bahagia & 1 & 2 & 2 & 2 & 2 & 2 & 2 & 2 & 1 & 1 \\
\hline 6 & Sugeh Bareng & 2 & 1 & 2 & 2 & 2 & 1 & 2 & 2 & 1 & 1 \\
\hline 7 & Sri Sari Wangi & 2 & 1 & 2 & 1 & 1 & 1 & 2 & 1 & 1 & 1 \\
\hline 8 & Makmur Jaya & 2 & 1 & 2 & 1 & 2 & 1 & 2 & 2 & 1 & 1 \\
\hline 9 & Harum Sari & 2 & 1 & 2 & 1 & 2 & 1 & 2 & 1 & 1 & 1 \\
\hline 10 & Brahman & 1 & 2 & 1 & 2 & 2 & 2 & 2 & 2 & 1 & 1 \\
\hline
\end{tabular}

- Langkah - langkah Metode WASPAS

Langkah-langkah yang digunakan dalam Metode WASPAS adalah sebagai berikut[15][2][11][14][16] :

1. Membuat Matriks Keputusan (X)

Langkah 1 : Menyusun kriteria dan alternatif ke dalam bentuk matriks.

Dari data yang didapat dijadikan data untuk matriks Keputusan (x). Pada langkah ini setiap kriteria dan alternatif disusun ke dalam bentuk matriks X;

Keterangan

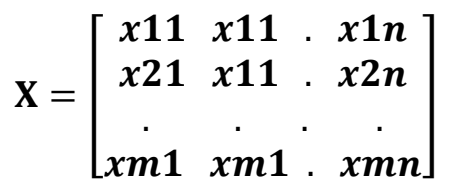

$\mathrm{m}$ : nomor urutan alternatif

$\mathrm{n}$ : nomor urutan kriteria

$\mathrm{X}$ : matriks keputusan

2. Menormalisasikan Matriks (X)

- Kriteria keuntungan:

$\boldsymbol{x i j}=\frac{\mathrm{xij}}{\operatorname{maxi} \mathrm{xij}}$.....

- Kriteria biaya : 
$x \boldsymbol{i} j=\frac{\operatorname{mini} x i j}{x i j}$.

Dimana :

$\mathrm{Xij}=$ Nilai kinerja alternatif sehubungan kriteria $\mathrm{j}$

Maxi Xij = Nilai maksimum dari setiap kolom dan baris

Mini Xij = Nilai minimum dari setiap kolom dan baris

Kriteria keuntungan(benefit) : jika nilai terbesar adalah terbaik

Kriteria biaya(cost) : jika nilai terkecil adalah terbaik

3. Menghitung Preferensi(Qi).

Untuk menghitung nilai Qi kita gunakan rumus :

$Q_{1}=0,5 \sum_{j=1}^{n} x i j w j+0,5 \prod_{j=1}^{n}(x i j) w j$

Dimana:

$0,5=$ Ketetapan

Qi $=$ Nilai Akhir dari Alternatif

$\mathrm{Wj}=$ Bobot yang ditentukan

$$
X=\left\{\begin{array}{cccccccccc}
\text { Tabel. 4 Matriks Keputusan X } \\
2 & 1 & 1 & 1 & 2 & 1 & 2 & 2 & 1 & 1 \\
1 & 1 & 2 & 2 & 2 & 1 & 2 & 2 & 1 & 1 \\
2 & 1 & 1 & 1 & 2 & 2 & 2 & 2 & 1 & 1 \\
2 & 1 & 2 & 2 & 2 & 2 & 2 & 1 & 1 & 1 \\
1 & 2 & 2 & 2 & 2 & 2 & 2 & 2 & 1 & 1 \\
2 & 1 & 2 & 2 & 2 & 1 & 2 & 2 & 1 & 1 \\
2 & 1 & 2 & 1 & 1 & 1 & 2 & 1 & 1 & 1 \\
2 & 1 & 2 & 1 & 2 & 1 & 2 & 2 & 1 & 1 \\
2 & 1 & 2 & 1 & 2 & 1 & 2 & 1 & 1 & 1
\end{array}\right\}
$$

Setelah terbentuk matriks keputusan $x$, selanjutnya melakukan normalisasi. Berikut ini adalah normalisasi data tersebut dengan menggunakan persamaan (1) karena seluruh kriteria bersifat keuntungan(benefit) seperti dibawah ini.

$$
x i j=\frac{x i j}{\operatorname{maxi} x i j} .
$$




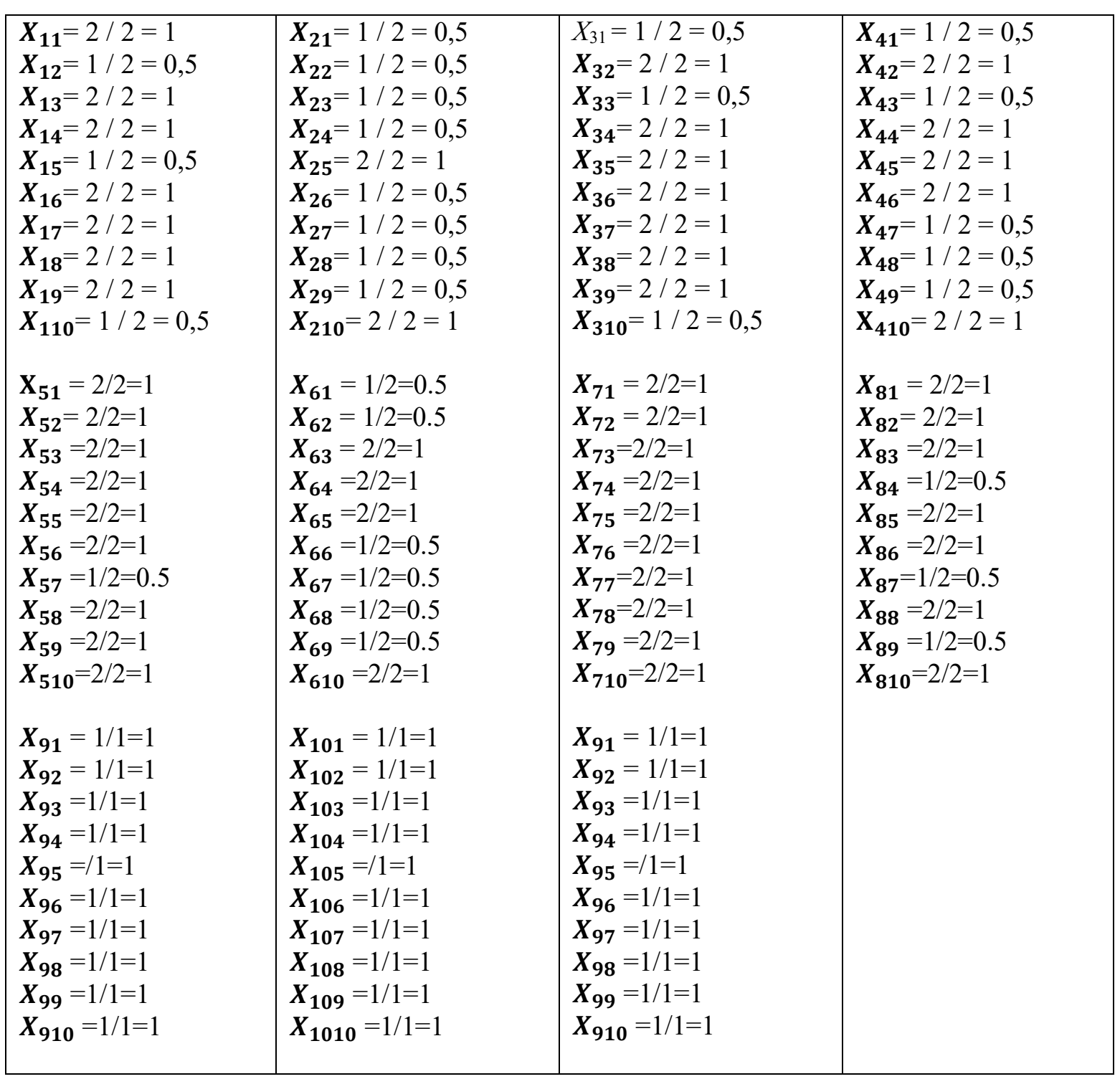

Perhitungan diatas merupakan hasil normallisasi dari matriks keputusan

Langkah selanjutnya yaitu menghitung preferensi (Qi) dengan menggunakan rumus di bawah ini:

$\mathbf{Q}_{1}=\mathbf{0}, \mathbf{5} \sum_{\mathbf{j}=\mathbf{1}}^{\mathbf{n}} \mathbf{x i j} \mathbf{w j}+\mathbf{0}, \mathbf{5} \prod_{\mathbf{j}=\mathbf{1}}^{\mathbf{n}}(\mathbf{x i j}) \mathbf{w j}$

$\mathrm{Q} 1=0,5 \sum(1 * 0,2)+(0,5 * 0,05)+(0.5 * 0,1)+(0,5 * 0,05)+(1 * 0,1)+(0.5 * 0,1)+(1 * 0,1)+$ $(1 * 0,05)+(1 * 0,15)+(1 * 0,1)+0.5 \prod(1) 0,2 *(0,5) 0,05 *(0.5) 0,1 *(0,5) 0,05 *(1) 0,1 *$ $(0.5) 0,1 *(1) 0,1 *(1) 0,05 *(1) 0,15 *(1) 0,1$

$=0,5 \sum(0,2+0,025+0,05+0,025+0,1+0,05+0,1+0,05+0,15+$ $0,1)+0.5 \prod(1 * 0,966 * 0,933 * 0,966 * 1 * 0,933 * 1 * 1 * 1 * 1)$

$=0,8311$

$\mathrm{Q} 2=0,5 \sum(0.5 * 0,2)+(0,5 * 0,05)+(1 * 0,1)+(1 * 0,05)+(1 * 0,1)+(0.5 * 0,1)+(1 * 0,1)+$ $(1 * 0,05)+(1 * 0,15)+(1 * 0,1)+0.5 \prod(0.5) 0,2 *(0,5) 0,05 *(1) 0,1 *(1) 0,05 *(1) 0,1 *$ $(0.5) 0,1 *(1) 0,1 *(1) 0,05 *(1) 0,15 *(1) 0,1$

$=0,5 \sum(0,1+0,025+0,1+0,05+0,1+0,05+0,1+0,05+0,15+$ $0,1)+0.5 \prod(0,871 * 0,966 * 1 * 1 * 1 * 0,933 * 1 * 1 * 1 * 1)$

$=0,8048$ 


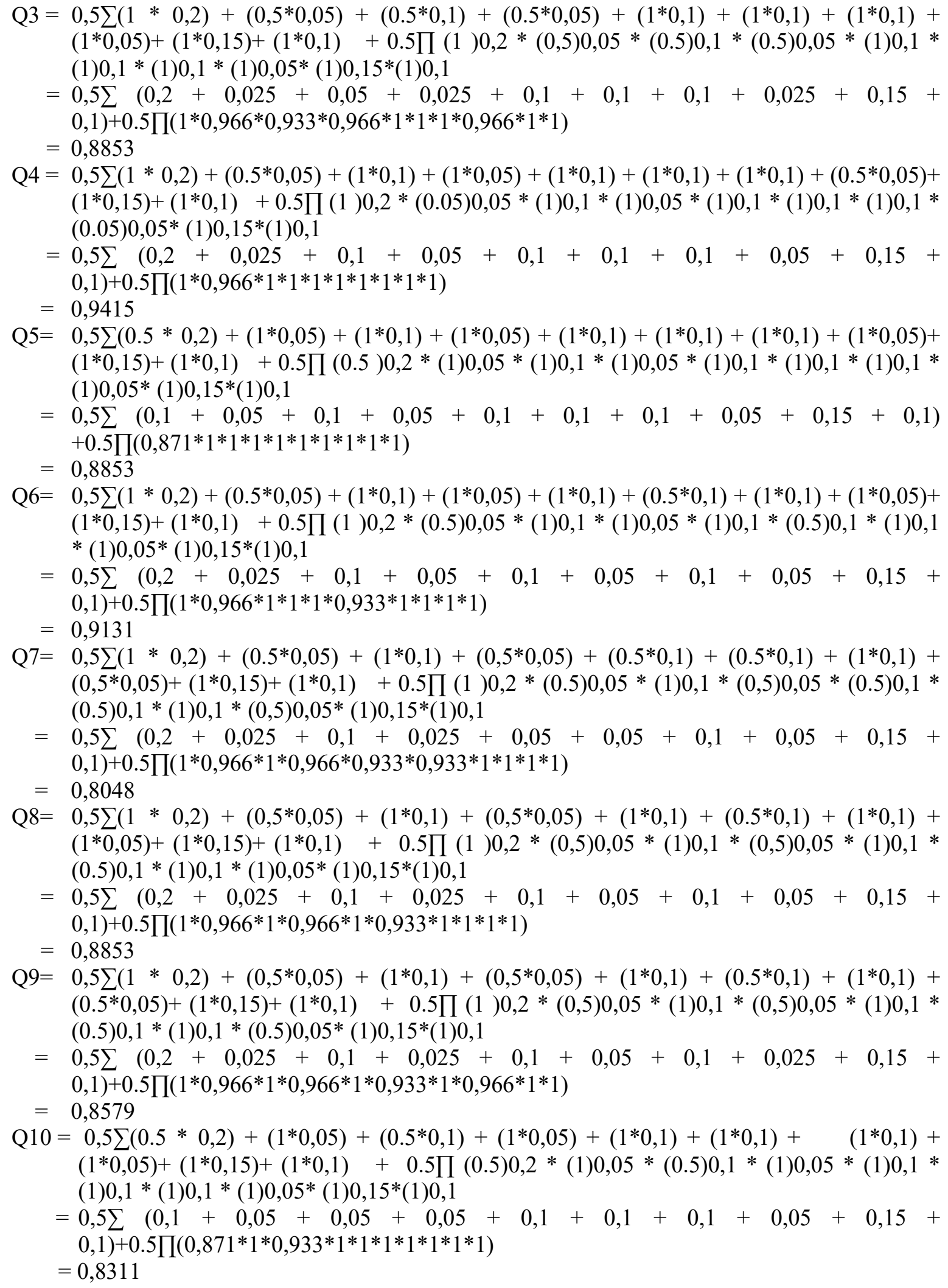

$=0,5 \sum(0,2+0,025+0,1+0,025+0,1+0,05+0,1+0,05+0,15+$ $0,1)+0.5 \prod(1 * 0,966 * 1 * 0,966 * 1 * 0,933 * 1 * 1 * 1 * 1)$

$=0,8853$

$\mathrm{Q} 9=0,5 \sum(1 * 0,2)+(0,5 * 0,05)+(1 * 0,1)+(0,5 * 0,05)+(1 * 0,1)+(0.5 * 0,1)+(1 * 0,1)+$ $(0.5 * 0,05)+(1 * 0,15)+(1 * 0,1)+0.5 \prod(1) 0,2 *(0,5) 0,05 *(1) 0,1 *(0,5) 0,05 *(1) 0,1 *$ $(0.5) 0,1 *(1) 0,1 *(0.5) 0,05 *(1) 0,15 *(1) 0,1$

$=0,5 \sum(0,2+0,025+0,1+0,025+0,1+0,05+0,1+0,025+0,15+$ $0,1)+0.5 \prod(1 * 0,966 * 1 * 0,966 * 1 * 0,933 * 1 * 0,966 * 1 * 1)$

$=0,8579$

$\mathrm{Q} 10=0,5 \sum(0.5 * 0,2)+(1 * 0,05)+(0.5 * 0,1)+(1 * 0,05)+(1 * 0,1)+(1 * 0,1)+\quad(1 * 0,1)+$ $(1 * 0,05)+(1 * 0,15)+(1 * 0,1)+0.5 \prod(0.5) 0,2 *(1) 0,05 *(0.5) 0,1 *(1) 0,05 *(1) 0,1 *$ $(1) 0,1 *(1) 0,1 *(1) 0,05 *(1) 0,15 *(1) 0,1$

$=0,5 \sum(0,1+0,05+0,05+0,05+0,1+0,1+0,1+0,05+0,15+$ $0,1)+0.5 \prod(0,871 * 1 * 0,933 * 1 * 1 * 1 * 1 * 1 * 1 * 1)$

$=0,8311$

Selanjutnya yang terakhir yaitu melakukan pengambilan keputusan. Berdasarkan perhitungan diatas, maka berikut ini adalah hasil penentuan kelayakan.

Tabel 5. Tabel Keputusan Nilai Qi

\begin{tabular}{|c|c|c|c|}
\hline Kode & Kelompok Ternak & Nilai Akhir & Rangking \\
\hline S-04 & Makmur II & 0,9415 & 1 \\
\hline
\end{tabular}




\begin{tabular}{|l|c|c|c|}
\hline S-06 & Sugeh Bareng & 0,9131 & 2 \\
\hline S-05 & Bahagia & 0,8853 & 3 \\
\hline S-03 & Makmur & 0,8853 & 4 \\
\hline S-08 & Makmur Jaya & 0,8853 & 5 \\
\hline S-09 & Harum Sari & 0,8579 & 6 \\
\hline S-10 & Brahman & 0,8311 & 7 \\
\hline S-01 & Karya Bakti & 0,8311 & 8 \\
\hline S-02 & Serba Guna & 0,8048 & 9 \\
\hline S-07 & Sri Sari Wangi & 0,8048 & 10 \\
\hline
\end{tabular}

Berdasarkan Nilai Qi yang Diperoleh dapat diambil kesimpulan bahwa Q4 atau S-04 yaitu Makmur II adalah alternatif yang memperoleh nilai tertinggi yang mana dialah alternatif terlayak untuk mendapatkan bantuan ternak.

\section{Use case Diagram}

Use case diagram merupakan interaksi antara 1 aktor atau lebih dengan sebuah sistem yang dibuat[12][13]. Gambar 2 menjelaskan Use Case Diagram Sistem Pendukung Keputusan Menentukan Kelayakan Bantuan Ternak Oleh Dinas Ketahanan Pangan dan Peternakan Provinsi Sumatera Utara Menggunakan Metode Weighted Aggregated Sum Product Assesment (WASPAS).

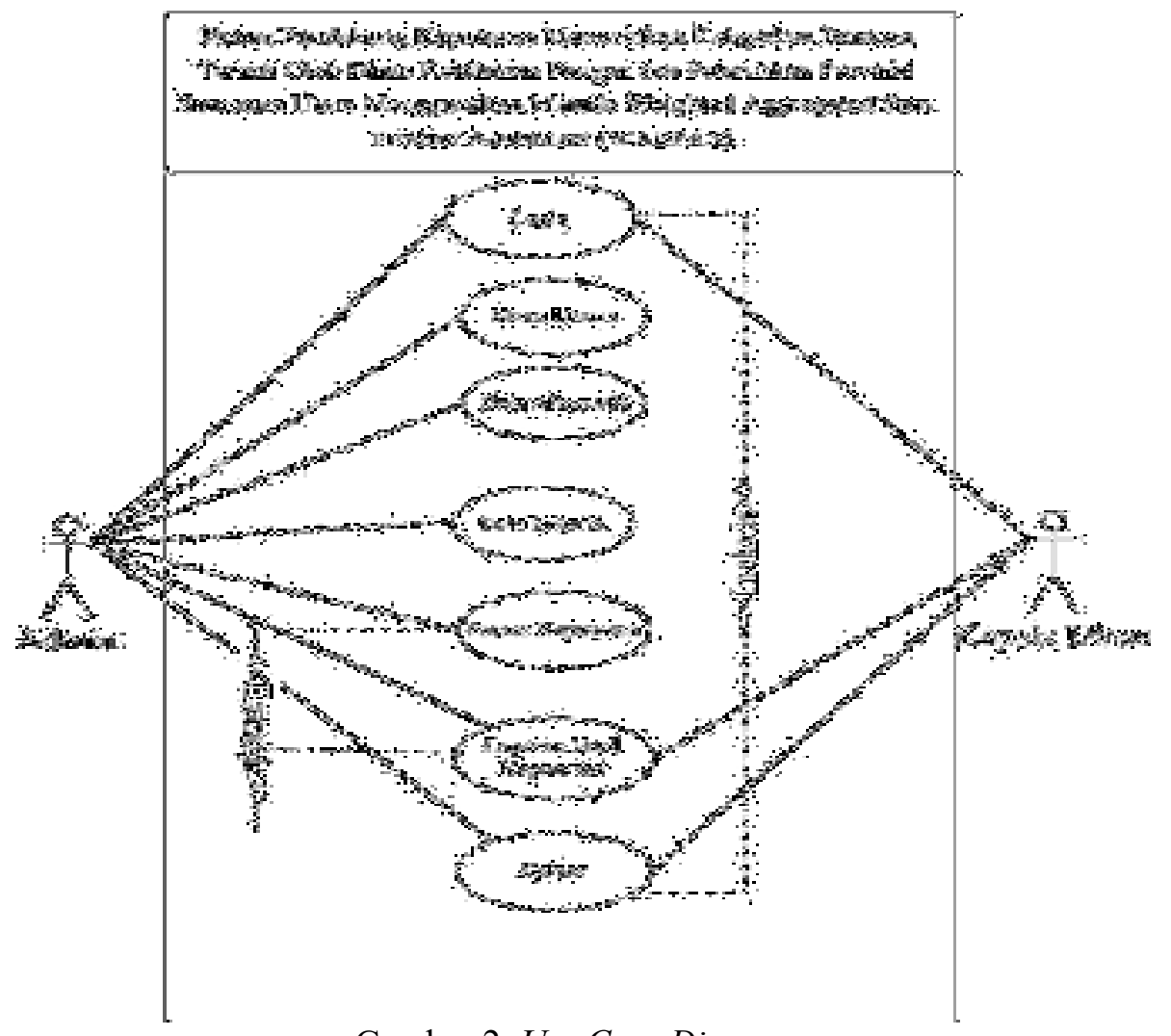

Gambar 2. Use Case Diagram.

\section{KESIMPULAN} berikut :

Berdasarkan pembahasan dan evaluasi sebelumnya, maka dapat ditarik kesimpulan sebagai

1. Perancangan aplikasi sistem pendukung keputusan dengan metode WASPAS dibuat dengan menggunakan aplikasi berbasis desktop yaitu Visual Basic 2010 dengan menggunakan Sq1 Server 2008 sebagai databasenya. Lalu dibuat tahapan desain interface 
form dan desain databasenya. Kemudian dilanjutkan perancangan kode program. Sehingga menghasilkan sistem pendukung keputusan yang dapat digunakan untuk menentukan kelayakan bantuan ternak dengan tepat.

2. Penerapan metode WASPAS pada sistem pendukung keputusan dilakukan dengan cara memasukkan setiap data alternatif dan kriteria serta memberikan nilai pada setiap alternatif dan memberikan bobot pada kriteria lalu disinkronkan dengan tahapan-tahapan pada metode WASPAS Sehingga akan menghasilkan alternatif yang terlayak mendapatkan bantuan ternak menggunakan metode WASPAS.

\section{SARAN}

Adapun saran untuk pengembangan lebih lanjut terhadap penelitian ini yaitu :

1. Diharapkan dapat ditambahkan data lain yang mendukung menentukan kelayakan bantuan ternak, misalnya penambahan alternative dan kriteria yang lebih banyak.

2. Sistem pendukung keputusan menentukan kelayakan bantuan ternak ini dapat dikembangkan lagi dengan menambahkan metode pengambilan keputusan lainnya sehingga hasilnya dapat dibandingkan, misalnya dengan metode TOPSIS atau SAW.

3. Aplikasi ini diharapkan dapat dikembangkan menjadi web based application atau aplikasi android karena aplikasi yang dibuat masih berbasis dekstop.

\section{UCAPAN TERIMA KASIH}

Penulis mengucapkan terimakasih yang sebesar-besarnya kepada Universitas Potensi Utama yang telah banyak memberikan masukkan dan saran dalam penyelesaian penelitian ini.

\section{DAFTAR PUSTAKA}

[1] Tanti, L., Puspasari, R., \& Triandi, B. (2018, August). Employee performance assessment with profile matching method. In 2018 6th International Conference on Cyber and IT Service Management (CITSM) (pp. 1-6). IEEE.

[2] Ickhsan, M., Anggraini, D., Haryono, R., Sahir, S. H., \& Rohminatin, R. (2018). Sistem Pendukung Keputusan Pemberian Kredit Usaha Rakyat Menggunakan Metode Weighted Aggregated Sum Product Assesment (WASPAS). JURIKOM (Jurnal Riset Komputer), 5(2), 97-102.

[3] Muslihudin, M. (2017). SISTEM PENDUKUNG KEPUTUSAN MENENTUKAN KELAYAKAN PENERIMAAN BANTUAN PENGUSAHA AYAM PETELUR OLEH DINAS PETERNAKAN KABUPATEN PESAWARAN MENGGUNAKAN METODE SIMPLE ADDITIVE WEIGHTING. Jurnal Pendidikan Teknologi dan Kejuruan, 14(2).

[4] Betrisandi, B. (2019). SISTEM PENDUKUNG KEPUTUSAN SELEKSI PENERIMA BANTUAN PEMBERDAYAAN UNTUK KELOMPOK PETERNAK SAPI MENGGUNAKAN METODE ARAS (ADDITIVE RATIO ASSESSMENT). Simtek: Jurnal Sistem Informasi dan Teknik Komputer, 4(1), 40-46.

[5] Ernawati, E., Hidayah, N. A., \& Fetrina, E. (2017). Rancang Bangun Sistem Pendukung Keputusan Kenaikan Jabatan Pegawai Dengan Metode Profile Matching (Studi Kasus: Kementerian Agama Kantor Wilayah DKI Jakarta). Studia Informatika: Jurnal Sistem Informasi, 10(2).

[6] Saputra, I., Sari, S. I., \& Mesran, M. (2017). PENERAPAN ELIMINATION AND CHOICE TRANSLATION REALITY (ELECTRE) DALAM PENENTUAN KULKAS TERBAIK. KOMIK (Konferensi Nasional Teknologi Informasi dan Komputer), 1(1).

[7] Ishak, R. (2016). Sistem Pendukung Keputusan Pemilihan Penyuluh Lapangan Keluarga Berencana Teladan Dengan Metode Weighted Product. ILKOM Jurnal Ilmiah, 8(3), 160166. 
[8] Widarma, A., \& Kumala, H. (2018). Sistem Pendukung Keputusan Dalam Menentukan Pengguna Listrik Subsidi Dan Nonsubsidi Menggunakan Metode Fuzzy Mamdani (Studi Kasus: PT. PLN Tanjung Balai). JurTI (Jurnal Teknologi Informasi), 2(2), 165-171.

[9] Imandasari, T., \& Windarto, A. P. (2017). Sistem Pendukung Keputusan dalam Merekomendasikan Unit Terbaik di PDAM Tirta Lihou Menggunakan Metode Promethee. Jurnal Teknologi dan Sistem Komputer, 5(4), 159-165.

[10] Manurung, S. (2018). Sistem Pendukung Keputusan Pemilihan Guru Dan Pegawai Terbaik Menggunakan Metode Moora. Simetris: Jurnal Teknik Mesin, Elektro dan Ilmu Komputer, 9(1), 701-706.

[11] Manalu, E., Sianturi, F. A., \& Manalu, M. R. (2017). Penerapan Algoritma Naive Bayes Untuk Memprediksi Jumlah Produksi Barang Berdasarkan Data Persediaan Dan Jumlah Pemesanan Pada Cv. Papadan Mama Pastries. Jurnal Mantik Penusa, 1(2).

[12] Urva, G., \& Siregar, H. F. (2015). Pemodelan UML E-Marketing Minyak Goreng. JURTEKSI ROYAL Edisi2.

[13] Aprianti, W., \& Maliha, U. (2016). Sistem Informasi Kepadatan Penduduk Kelurahan Atau Desa Studi Kasus Pada Kecamatan Bati-Bati Kabupaten Tanah Laut. Jurnal Sains dan Informatika, 2(1).

[14] Hutagalung, S. Y., Pratiwi, F., \& Wijaya, I. (2018, July). Penerapan Metode Weighted Aggregated Sum Product Assesment (WASPAS) Dalam Keputusan Penerimaan Beasiswa. In Seminar Nasional Sains dan Teknologi Informasi (SENSASI) (Vol. 1, No. 1).

[15] Marbun, R. E., Hidayati, T., \& Parhusip, E. (2018, July). Sistem Pendukung Keputusan Pemberian Kartu Indonesia Pintar (KIP) Menggunakan Metode Weighted Aggregated Sum Product Assesment (WASPAS). In Seminar Nasional Sains dan Teknologi Informasi (SENSASI) (Vol. 1, No. 1).

[16] Sianturi, M., Tarigan, J., Rizanti, N. P., \& Cahyadi, A. D. (2018, July). Sistem Pengambilan Keputusan Pemilihan Jurusan Terbaik Pada SMK Menerapkan Metode Weight Aggregated Sum Product Assesment (WASPAS). In Seminar Nasional Sains dan Teknologi Informasi (SENSASI) (Vol. 1, No. 1). 